Jurnal Ilmiah Mahasiswa Kendali dan Listrik
Vol. 1, No. 1, June 2020,14 - 22

\title{
PENGEMBANGAN ALAT UKUR BATAS KAPASITAS TAS SEKOLAH ANAK BERBASIS MIKROKONTROLER
}

\author{
Putri Oktarin $^{1}$, Novia Utamu Putri ${ }^{2}$, Risky Setiawan ${ }^{3}$ \\ ${ }^{\text {I} P r o g r a m ~ S t u d i ~ D 3 ~ T e k n i k ~ K o m p u t e r, ~ F a k u l t a s ~ T e k n i k ~ d a n ~ I l m u ~ K o m p u t e r, ~ U n i v e r s i t a s ~ T e k n o k r a t ~ I n d o n e s i a ~}$ \\ ${ }^{2,3}$ Program Studi S1 Teknik Elektro, Fakultas Teknik dan Ilmu Komputer, Universitas Teknokrat Indonesia \\ putrioktari@gmail.com ${ }^{1}$, novia.utamiputri@gmail com², riskysetiawan231@gmail.com
}

\begin{abstract}
Backpacks are often used by school children as a container or a place to carry their school materials and equipment, so these types of backpacks are very popular with school children. The large number of students wearing backpacks to school can be proven from the results of a survey conducted at SD N Bumisari, Natar District, South Lampung. Of the total number of subjects, 456 elementary school students carried 404 students (88.6\%), and 52 students (11.4\%) carried sling bags. But they rarely pay attention to the weight of the burden on the bag he carries everyday which turns out to cause injury to back pain.

The tool is made in the form of a wearable device where the tool is in the form of a backpack that can be carried anywhere without having to require AC current as input voltage to the tool, because the power uses DC current with a voltage of $5 \mathrm{~V}$, the device is made using a microcontroller supported by a $10 \mathrm{~kg}$ loadcell sensor, modules HX711, keypad, plus an indicator component in the form of a buzzer. If the bag load exceeds the safe limit, the buzzer indicator will sound.
\end{abstract}

Keywords: Arduino Uno, Backpack, HX711 Module, Loadcell

\begin{abstract}
Abstrak
Tas ransel sering digunakan anak sekolah sebagai sebuah wadah atau tempat untuk membawa bahan dan peralatan sekolah mereka, sehingga tas jenis ransel ini sangat diminati oleh anak sekolah. Banyaknya siswa yang mengenakan tas punggung ke sekolah dapat dibuktikan dari hasil survei yang telah dilakukan di SD N Bumisari, Kecamatan Natar, Lampung Selatan. Dari jumlah subjek sebanyak 456 siswa sekolah dasar, yang membawa tas punggung sebanyak 404 siswa $(88,6 \%)$, dan yang membawa tas selempang sebanyak 52 siswa $(11,4 \%)$. Namun meraka jarang memperhatikan berat beban pada tas yang dipikulnya sehari-hari yang ternyata dapat menimbulkan cidera nyeri punggung.

Alat yang dibuat berupa wearable device dimana alat berupa sebuah tas punggung yang dapat dibawa kemanapun tanpa harus membutuhkan arus AC sebagai tegangan inputan ke alat, dikarenakan daya menggunakan arus DC dengan tegangan sebesar $5 \mathrm{~V}$, alat yang dibuat menggunakan mikrokontroler yang didukung loadcell sensor 10 $\mathrm{kg}$, modul HX711, keypad, ditambah juga dengan komponen indikator berupa buzzer. Jika berat beban tas melebihi batas aman, maka indikator buzzer akan berbunyi.
\end{abstract}

Kata kunci : Arduino Uno, Tas Punggung, Modul HX711, Loadcell.

To cite this article:

Authors. (2020). Title of the article. Jurnal Ilmiah Mahasiswa Kendali dan Listrik, Vol: 1, No: 1, Hal. 14 - 22 


\section{PENDAHULUAN}

Tas sekolah menjadi bagian yang tak terpisahkan dari siswa sekolah sehingga identik dengan mereka. Tas sekolah digunakan sebagai wadah buku dan alat sekolah lainnya untuk dibawa ke sekolah. Sementara, dari berbagai jenis yang ada, tas punggung merupakan tas yang banyak digunakan.

Banyaknya siswa yang mengenakan tas punggung ke sekolah dapat dibuktikan dari hasil survei yang telah dilakukan di SD N Bumisari, Kecamatan Natar, Lampung Selatan. Dari jumlah subjek sebanyak 456 siswa sekolah dasar, yang membawa tas punggung sebanyak 404 siswa $(88,6 \%)$, dan yang membawa tas selempang sebanyak 52 siswa $(11,4 \%)$.

Saat usia dini masa sekolah dasar, tulang masih dalam proses pertumbuhan dan akan mengalami gangguan apabila mengangkat beban lebih berat dari berat badannya. Sehingga mengakibatkan berbagai gangguan pada tulang. Seperti bungkuk atau tulang tidak dapat tumbuh dengan normal [1].

Kecenderungan saat ini sekolah sering memberi pekerjaan rumah, tugas-tugas, dan kegiatan ekstra kurikuler yang berdampak pada banyaknya material yang harus dibawa siswa ke sekolah. Oleh karena itu seorang anak seharusnya mulai memperhatikan berat beban yang dipikulnya seharihari [2].

Kerja berlebih pada otot anak usia sekolah dapat menimbulkan cidera nyeri punggung. Punggung merupakan bagian belakang tubuh yang terletak antara pinggang dan kepala. Cidera nyeri puggung atau keluhan mukuloskeletal dapat terjadi dikarenakan beberapa faktor, seperti membawa beban yang terlalu berat, cara membawa tas yang salah serta durasi dalam membawa tas [3].

American Occupational Therapy Associaton (AOTA) dan American Physical Therapy Association (APTA) menyimpulkan bahwa berat tas punggung sekolah seharusnya tidak lebih dari $10 \%$ berat badan anak, didasarkan pada fakta bahwa hal itu dapat mempengaruhi postur tulang belakang, bentuk kaki dan gaya berjalan mereka [4].

\section{METODE PENELITIAN}

\section{Experimen}

Metode yang digunakan pada penelitian ini adalah menggunakan eksperimen, dimana dilakukan percobaan sampai mendapatkan ahai yang sesuai. Langkah pertama dalam perancangan sistem adalah membuat suatu diagram blok dari sistem yang akan dibuat, dimana setiap blok mempunyai fungsi tertentu dan gabungan dari tiap-tiap blok tersebut akan membentuk suatu sistem. Dari blok diagram maka dapat diketahui prinsip kerja rangkaian keseluruhan.

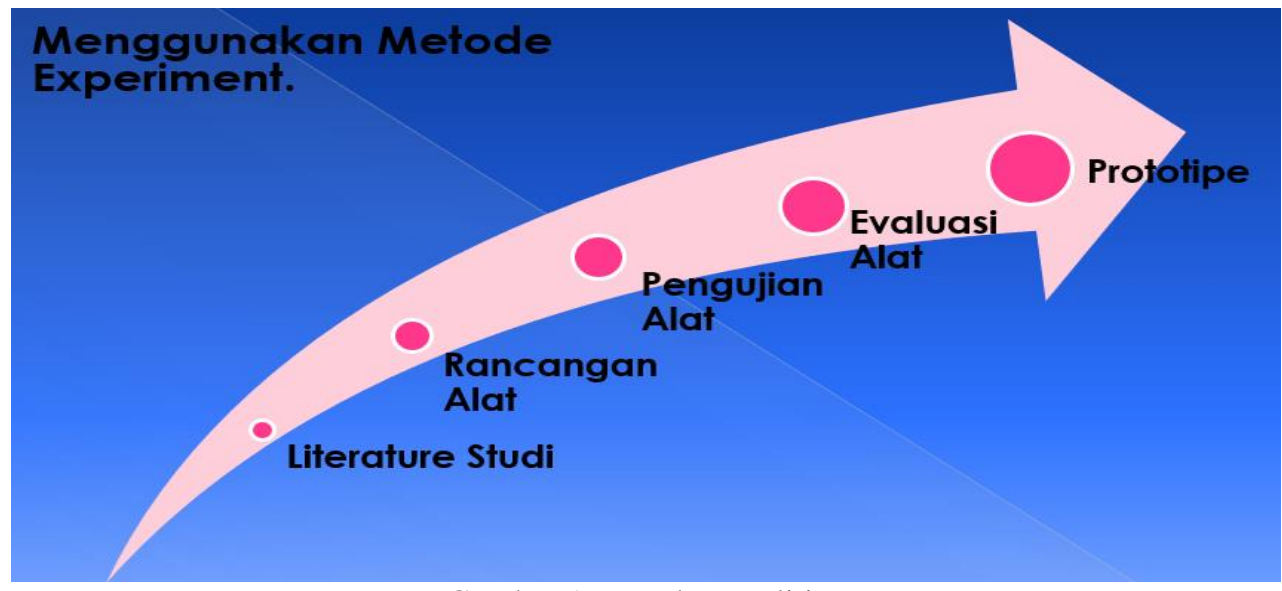

Gambar 1 Metode Penelitian 
Proses studi literatur melibatkan pencarian dasar-dasar teori dan penelitian pendampingan yang telah dilakukan sebelumnya. Teori-teori yang terkait dengan permasalahan penelitian seperti, dasar-dasar rangkaian elektronika digital, komponen elektronika pendukung, bahasa pemrograman C Arduino Uno dan teori pendukung lain yang berusaha digali oleh penulis dengan menuliskan secara singkat dan telah disesuaikan dengan tingkatan yang diperlukan dalam penelitian ini. Dalam studi literatur dilakukan pencarian informasi mengenai segala sesuatu yang berkaitan dengan penelitian ini, diantaranya adalah sebagai berikut :

1. Cara kerja dan pemrograman mikrokontroler Arduino Uno.

Arduino Uno R3 adalah papan pengembangan mikrokontroler yang berbasis chip ATmega328P. Arduino Uno memiliki 14 digital pin input / output (atau biasa ditulis I/O, dimana 14 pin diantaranya dapat digunakan sebagai output PWM antara lain pin 0 sampai 13), 6 pin input analog, menggunakan crystal $16 \mathrm{MHz}$ antara lain pin A0 sampai A5, koneksi USB, jack listrik, header ICSP dan tombol reset. Hal tersebut adalah semua yang diperlukan untuk mendukung sebuah rangkaian mikrokontroler [5].

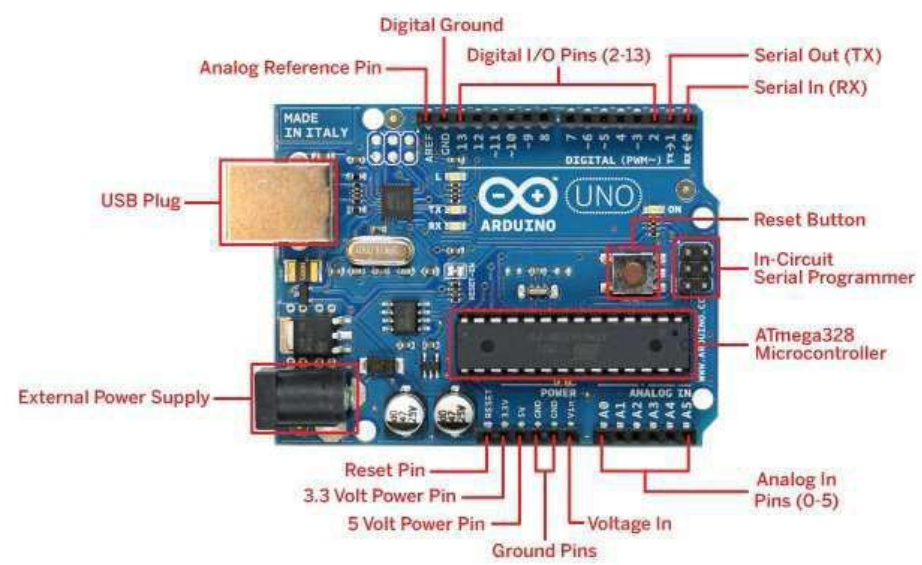

Gambar 2 Arduino Uno

2. Spesifikasi modul HX711 yang akan digunakan.

3. Cara kerja sensor yang digunakan dan pengujian sensor.

4. Karakteristik komponen - komponen yang digunakan.

Studi literatur dilakukan dengan membaca langsung dari media buku, beberapa jurnal penelitian terdahulu dan internet. Penelitian ini berfokus pada loadcell $10 \mathrm{~kg}$ dengan modul HX711, dan yang merupakan alat kendali paling utama adalah Arduino Uno.

\section{HASIL DAN PEMBAHASAN}

\subsection{Cara Kerja Sistem}

Sistem yang dirancang pada alat ini bekerja dengan memberikan peringatan alarm batas kapasitas tas ransel anak sekolah. Cara pengoperasiannya dengan menginputkan berat badan anak melalui keypad, uji dengan menempatkan beban diatas loadcell, lalu berikan beban alat dengan berat yang bervariasi [6]. Jika berat beban yang dimasukkan ke dalam tas ransel lebih dari 10\% berat badan anak maka buzzer akan berbunyi, dan LCD akan menampilkan berat tas (berat beban) dan berat maksimal tas ransel. 


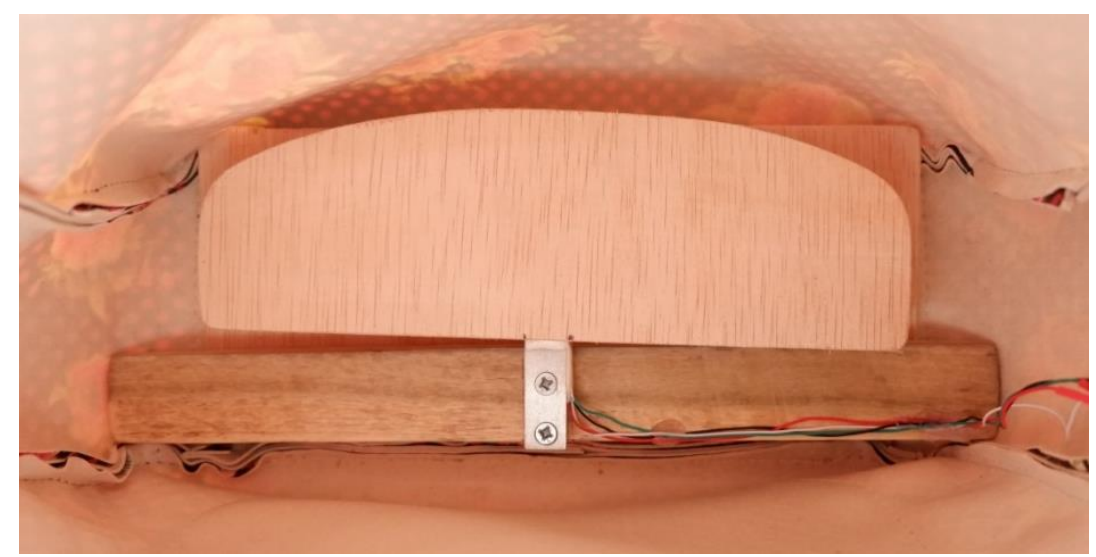

Gambar 2. Rancangan Mekanik

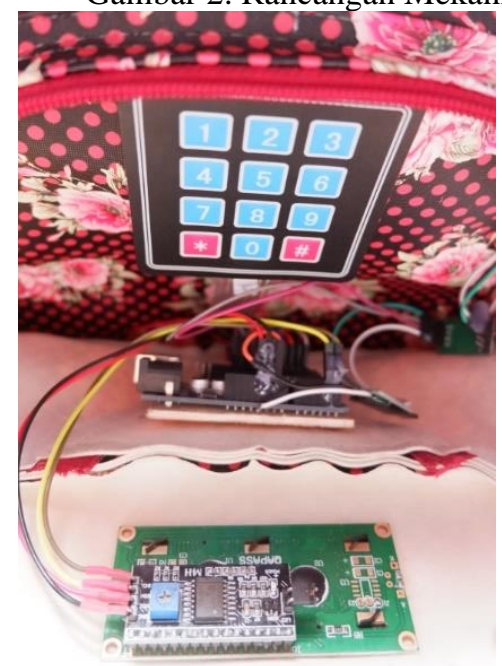

\subsection{Pengujian}

Gambar 3. Rancangan Elektronika

Tahap berikutnya dalah Pengujian. Pada tahap ini adalah pengujian komunikasi mikrokontroler arduino dengan modul LCD 20x4, pada alat ini modul lcd 20x4 digunakan sebagai monitor untuk mengetahui kondisi kerja sistem pemantauan lebih mudah [7]. Hasil pengujian akan dimanfaatkan untuk menyempurnakaan kinerja sistem. Pengujian sistem ini terdiri dari beberapa tahapan, dimulai dari pengujian terhadap tiap-tiap bagian pendukung sistem hingga pengujian sistem secara keseluruhan. Dari hasil pengujian maka dapat dianalisa kinerja-kinerja dari tiap-tiap bagian sistem sehingga terbentuklah tas ransel anak sekolah berbasis mikrokontroler. Pengujian terhadap keseluruhan sistem berguna untuk mengetahui bagaimana kinerja dan tingkat keberhasilan dari sistem tersebut.

Tahapan pengujian akan dilakukan dengan urutan sebagai berikut :

1. Pengujian Loadcell

2. Pengujian Keypad 3X4

3. Pengujian Buzzer

4. Pengujian LCD $16 \mathrm{X} 2$

5. Pengujian Catu Daya

6. Pengujian Sistem Keseluruhan

\subsubsection{Pengujian Loadcell}

Pengujian ini merupakan langkah awal untuk mendapatkan hasil pengukuran dan data yang diperlukan untuk mendapatkan berat isi tas ransel anak sekolah. Hasil pengukuran bisa dilihat dari tampilan LCD. Untuk pengujian terhadap objek dilakukan dengan memberikan beban di diatas loadcell. Pengujian dilakukan sebanyak 3 kali. Setelah itu lihat dan catat perubahan berat beban yang terbaca oleh loadcell 
sensor, serta membandingkan antara berat beban yang terbaca loadcell sensor dengan berat beban sebenarnya.

Tabel 4.1. Hasil Pengujian Keakuratan Loadcell

\begin{tabular}{|c|c|c|c|c|c|c|c|}
\hline \multirow{2}{*}{$\begin{array}{l}\text { Nama } \\
\text { Barang }\end{array}$} & \multirow[t]{2}{*}{ Jumlah } & \multicolumn{4}{|c|}{$\begin{array}{l}\text { Berat Beban Hasil Pengukuran } \\
\text { Loadcell }\end{array}$} & \multirow{2}{*}{$\begin{array}{l}\text { Berat Beban } \\
\text { Sebenarnya }\end{array}$} & \multirow{2}{*}{$\begin{array}{l}\text { Error } \\
(\%)\end{array}$} \\
\hline & & $\mathrm{Ke}-1$ & $\mathrm{Ke}-2$ & $\mathrm{Ke}-3$ & $\begin{array}{l}\text { Rata- } \\
\text { Rata }\end{array}$ & & \\
\hline Kamus & 1 buah & 0.20 & 0.19 & 0.19 & 0.19 & $0.19 \mathrm{~kg}$ & $0.00 \%$ \\
\hline Aqua & $600 \mathrm{ml}$ & 0.60 & 0.60 & 0.60 & 0.60 & $0.59 \mathrm{~kg}$ & $1.66 \%$ \\
\hline $\begin{array}{l}\text { Buku } \\
\text { Paket }\end{array}$ & 4 buah & 1.57 & 1.57 & 1.56 & 1.56 & $1.56 \mathrm{~kg}$ & $0.00 \%$ \\
\hline $\begin{array}{l}\text { Buku } \\
\text { Tulis }\end{array}$ & 4 buah & 0.39 & 0.39 & 0.38 & 0.38 & $0.38 \mathrm{~kg}$ & $0.00 \%$ \\
\hline $\begin{array}{l}\text { Kotak } \\
\text { Makan }\end{array}$ & 1 kotak & 0.33 & 0.32 & 0.32 & 0.32 & $0.31 \mathrm{~kg}$ & $3.12 \%$ \\
\hline
\end{tabular}

Dari Tabel 4.1. ditampilkan hasil keseluruhan pengujian dan pengukuran berat beban menggunakan sensor loadcell. Pengukuran dan perhitungan yang didapat dari $600 \mathrm{ml}$ Aqua adalah sebagai berikut :

Rata-rata berat beban $=\frac{\text { total }}{\text { jumlah data }}=\frac{0.60+0.60+0.60}{3}=0.60 \mathrm{~kg}$

Error $=\frac{\text { nilai terbaca }- \text { nilai sebenarnya }}{\text { nilai terbaca }} \times 100=\frac{0.60-0.59}{0.60} \times 100=1.66 \%$

\subsubsection{Pengujian Keypad 3X4}

Pengujian ini dilakukan untuk mengetahui kebenaran prinsip kerja mikrokontroler melalui keypad, yaitu dengan cara memasukkan kode-kode yang telah disimpan kedalam memori mikrokontroler. Keypad digunakan untuk menginputkan berat anak yang nantinya akan ditampilkan pada LCD [8]. Pengujian keypad dapat dilihat pada Gambar 4.

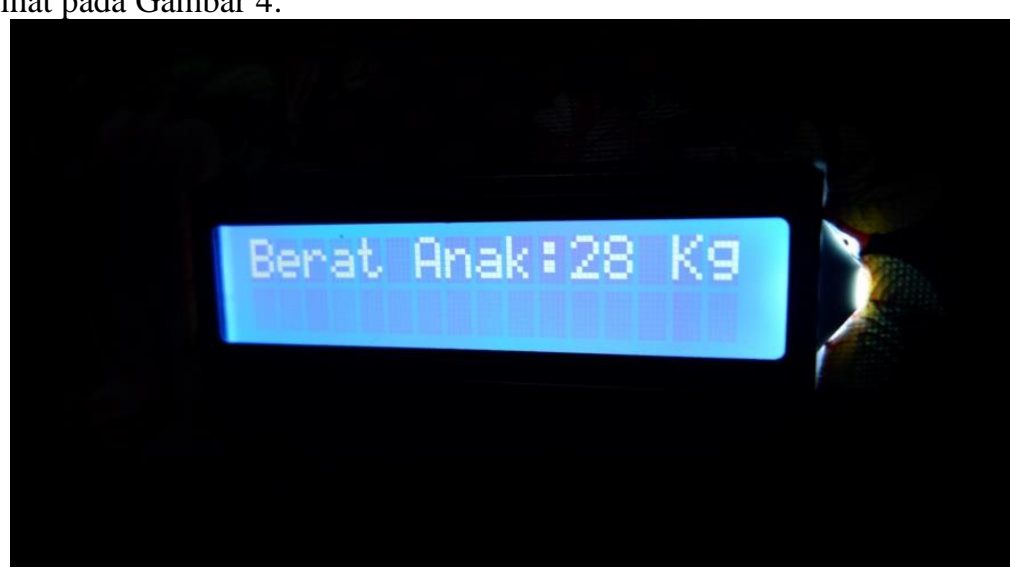

\subsubsection{Pengujian Buzzer}

Gambar 4. Pengujian Keypad Penginputan Berat Anak

Pada penjelasan ini buzzer digunakan untuk memberikan peringatan atau isyarat bahwa beban yang dimasukkan kedalam tas melebihi batas kapasitas tas ransel yang baik.

Hasil pengukuran rangkaian buzzer dapat dilihat pada Tabel 4.2., dibawah ini :

Tabel 1 Hasil Pengujian Buzzer Isi Tas Ransel

\begin{tabular}{|l|l|l|l|l|}
\hline No & Input Berat & $\begin{array}{l}\text { Berat Isi Tas Deteksi } \\
\text { Loadcell }(\mathrm{kg})\end{array}$ & Status & Buzzer \\
\hline
\end{tabular}


Jurnal Ilmiah Mahasiswa Kendali danListrik (JIMEL), Vol: 1, No: 1, Hal. 14 - 22

\begin{tabular}{|l|l|l|l|l|}
\hline 1 & $28 \mathrm{~kg}$ & $1,9 \mathrm{~kg}$ & Normal & $\begin{array}{l}\text { Tidak } \\
\text { Berbunyi }\end{array}$ \\
\hline 2 & $28 \mathrm{~kg}$ & $2,1 \mathrm{~kg}$ & Normal & $\begin{array}{l}\text { Tidak } \\
\text { Berbunyi }\end{array}$ \\
\hline 3 & $28 \mathrm{~kg}$ & $2,6 \mathrm{~kg}$ & Normal & $\begin{array}{l}\text { Tidak } \\
\text { Berbunyi }\end{array}$ \\
\hline 4 & $28 \mathrm{~kg}$ & $3,0 \mathrm{~kg}$ & Peringatan & Berbunyi \\
\hline 5 & $28 \mathrm{~kg}$ & $3,4 \mathrm{~kg}$ & Peringatan & Berbunyi \\
\hline
\end{tabular}

\subsubsection{Pengujian LCD 16X2}

Pengujian LCD dilakukan untuk mengetahui apakah LCD dapat menampilkan tampilan sesuai dengan program yang dimasukkan dan dapat menerima input dari keypad untuk memasukkan nilai yang diinginkan [9]. Disini LCD akan menampilkan "Tas Pintar Putri Oktari", lalu saat berat badan anak diinputkan melalui keypad maka LCD akan menampilkan "Berat Anak = ", setelah beban dimasukkan kedalam tas LCD akan menampilkan "Berat Tas $=. . . "$ "Berat Max $=.$. " Tampilan LCD dapat dilihat pada gambar dibawah.

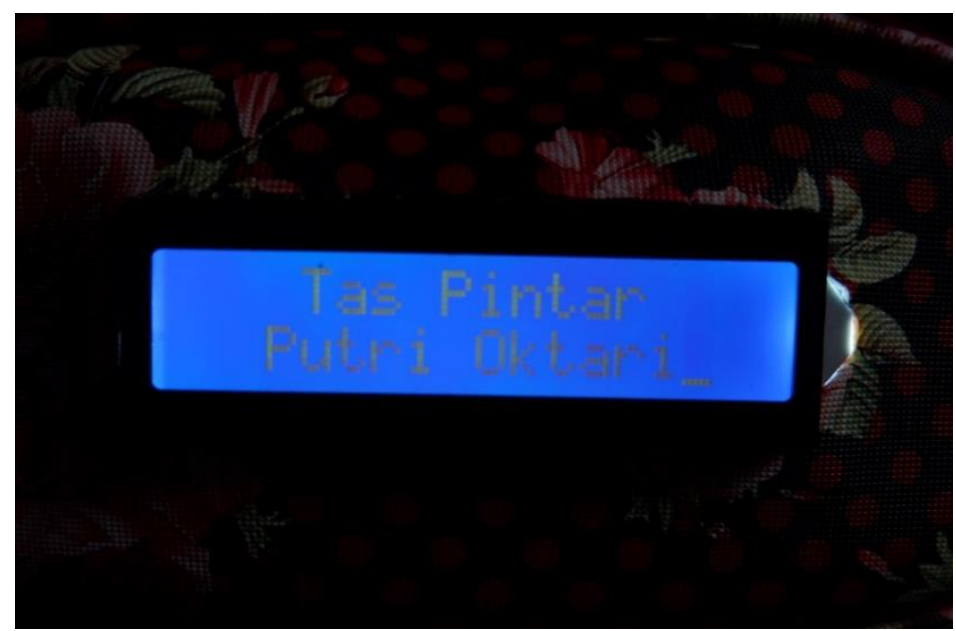

Gambar 5. Tampilan Awal LCD

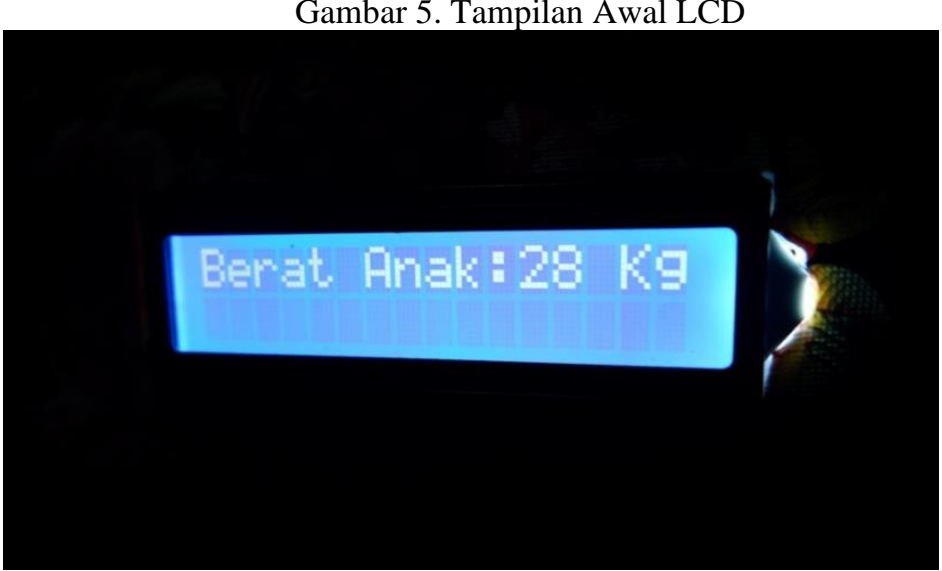

Gambar 6. Tampilan LCD Input Berat Anak 


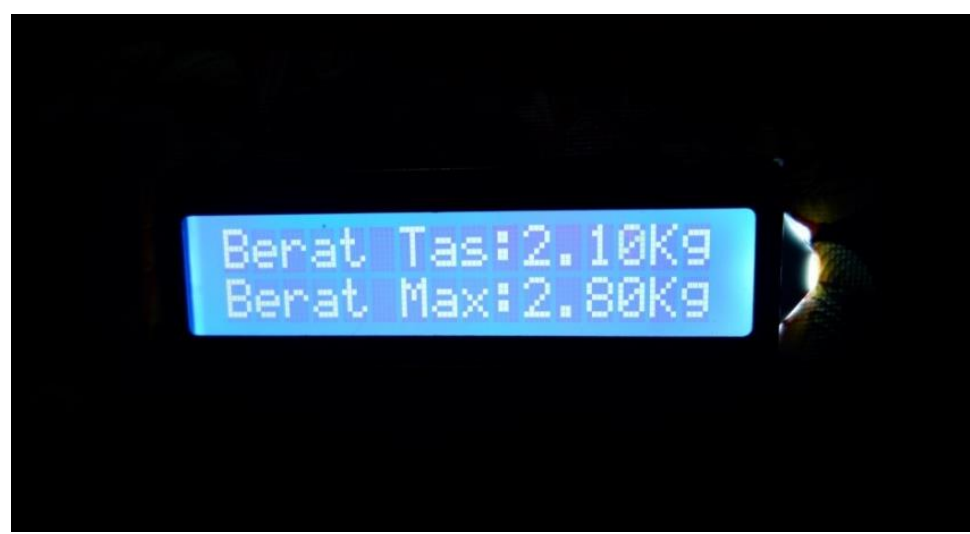

\subsubsection{Pengujian Catu Daya}

Gambar 7. Tampilan LCD Saat Sudah Input Beban

Pengujian ini bertujuan untuk memastikan apakah daya yang dihasilkan oleh baterai dapat digunakan secara utuh oleh mikrokontroler, LCD, serta buzzer yang membutuhkan daya antara 3 - 24 Volt. Alat yang digunakan dalam pengujian ini yaitu multitester digital yang dihubungkan dengan pin GND dan VIN.

Tegangan catu daya yang dibutuhkan dapat dilihat pada Gambar 4.7., dibawah :

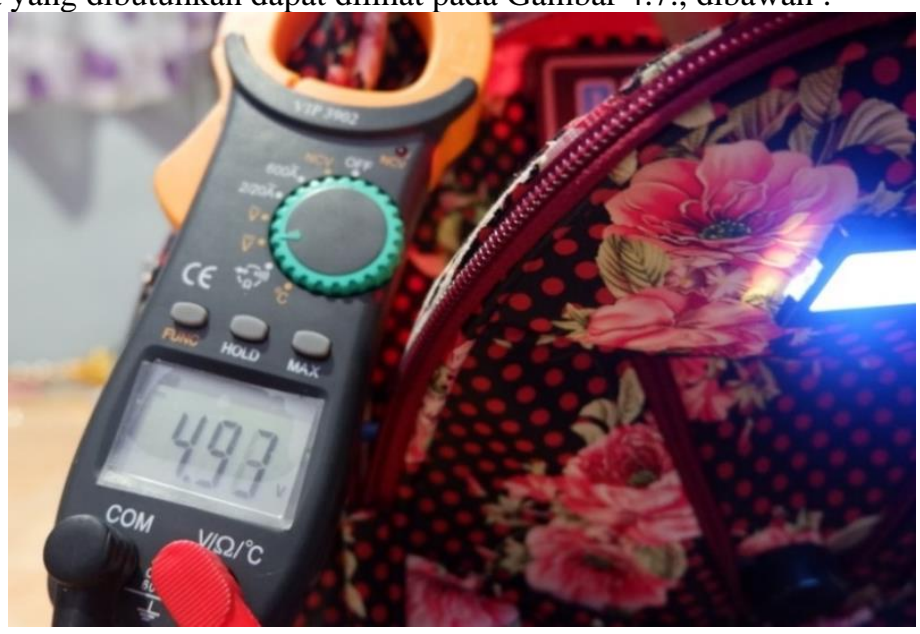

Gambar 8. Pengujian Catu Daya

\subsubsection{Pengujian Sistem Keseluruhan}

Untuk mengetahui rangkaian catu daya apakah berfungsi sesuai yang diharapkan, maka pada tahap ini dilakukan pengujian dengan cara memberikan supply daya berukuran 5 volt dan mengukur keluaran daya yang dikeluarkan dari rangkaian tersebut dengan menggunakan multitester[10]. Pengujian dilakukan untuk mengetahui apakah alat dapat berfungsi dengan baik secara keseluruhan baik dalam rangkaian mekanik ataupun rangkaian elektronika. Pengujian alat secara keseluruhan ini dimulai dengan penginputan berat badan, pembacaan berat isi tas, dan alarm peringatan. Berikut hasil pengujian secara keseluruhan dapat dilihat pada Tabel 1 yaitu :

Tabel 2 Pengujian Secara Keseluruhan

\begin{tabular}{|l|l|l|}
\hline Percobaan & Indikator & Keterangan \\
\hline \multirow{4}{*}{} & Tampilan “Tas Pintar Putri Oktari” & Berhasil \\
\cline { 2 - 3 } & Input Berat Anak & $28 \mathrm{~kg}$ \\
\cline { 2 - 3 } & Input Berat Beban & $1.60 \mathrm{~kg}$ \\
\hline
\end{tabular}


Jurnal Ilmiah Mahasiswa Kendali danListrik (JIMEL), Vol: 1, No: 1, Hal. 14 - 22

\begin{tabular}{|l|l|l|}
\hline Percobaan 1 & Tampilan Berat Tas & $2.39 \mathrm{~kg}$ \\
\cline { 2 - 3 } & Tampilan Berat Max & $2.80 \mathrm{~kg}$ \\
\cline { 2 - 3 } & Buzzer & Tidak Berbunyi \\
\cline { 2 - 3 } & Status & Normal \\
\hline \multirow{5}{*}{ Percobaan 2 } & Tampilan “Tas Pintar Putri Oktari” & Berhasil \\
\cline { 2 - 3 } & Input Berat Anak & $28 \mathrm{~kg}$ \\
\cline { 2 - 3 } & Input Berat Beban & $1.00 \mathrm{~kg}$ \\
\cline { 2 - 3 } & Tampilan Berat Tas & $1.70 \mathrm{~kg}$ \\
\cline { 2 - 3 } & Tampilan Berat Max & $2.80 \mathrm{~kg}$ \\
\cline { 2 - 3 } & Buzzer & Tidak Berbunyi \\
\cline { 2 - 3 } & Status & Normal \\
\hline
\end{tabular}

\begin{tabular}{|l|l|l|}
\hline Percobaan & Indikator & Keterangan \\
\hline \multirow{5}{*}{ Percobaan 3 } & Tampilan "Tas Pintar Putri Oktari” & Berhasil \\
\cline { 2 - 3 } & Input Berat Anak & $28 \mathrm{~kg}$ \\
\cline { 2 - 3 } & Input Berat Beban & $2.30 \mathrm{~kg}$ \\
\cline { 2 - 3 } & Tampilan Berat Tas & $3.09 \mathrm{~kg}$ \\
\cline { 2 - 3 } & Tampilan Berat Max & $2.80 \mathrm{~kg}$ \\
\cline { 2 - 3 } & Buzzer & Berbunyi \\
\cline { 2 - 3 } & Status & Peringatan \\
\hline \multirow{5}{*}{ Percobaan 4 } & Tampilan "Tas Pintar Putri Oktari” & Berhasil \\
\cline { 2 - 3 } & Input Berat Anak & $28 \mathrm{~kg}$ \\
\cline { 2 - 3 } & Input Berat Beban & $3.00 \mathrm{~kg}$ \\
\cline { 2 - 3 } & Tampilan Berat Tas & $3.79 \mathrm{~kg}$ \\
\cline { 2 - 3 } & Tampilan Berat Max & $2.80 \mathrm{~kg}$ \\
\cline { 2 - 3 } & Buzzer & Berbunyi \\
\cline { 2 - 3 } & Status & Peringatan \\
\hline \multirow{5}{*}{ Percobaan 5 } & Tampilan "Tas Pintar Putri Oktari” & Berhasil \\
\cline { 2 - 3 } & Input Berat Anak & $28 \mathrm{~kg}$ \\
\hline & Input Berat Beban & $3.40 \mathrm{~kg}$ \\
\cline { 2 - 3 } & Tampilan Berat Tas & $4.15 \mathrm{~kg}$ \\
\hline & Tampilan Berat Max & $2.80 \mathrm{~kg}$ \\
\hline & Buzzer & Berbunyi \\
\hline & Status & Peringatan \\
\hline
\end{tabular}

Dari Tabel 2. diatas ditampilkan hasil pengujian secara keseluruhan. Pengukuran dan perhitungan tampilan berat tas yang didapat dari percobaan 1 adalah sebagai berikut :

Tampilan berat tas $=$ Berat tas + Berat beban hasil pengukuran loadcell

$$
\begin{aligned}
& =0.69+1.70 \\
& =2.39 \mathrm{~kg}
\end{aligned}
$$

\section{SIMPULAN}

Dari hasil pembuatan alat ukur batas kapasitas tas sekolah anak bebasis mikrokontroler ini, serta dari hasil percobaan yang telah dilakukan, maka dapat disimpulkan beberapa hal sebagai berikut:

1. Dari hasil pengujian didapatkan bahwa tas ransel yang telah dibuat oleh penulis dapat bekerja dengan baik, dapat di terapkan pada anak sekolah dasar.

2. Loadcell berjalan baik dengan pengkalibrasian selisih keakurasian kurang dari 5\% dengan pengukuran penimbangan beban posisi tegak lurus.

3. Range status level normal berat isi tas dengan rentang $0 \mathrm{~s} / \mathrm{d} 10 \%$, dan range status peringatan dengan berat isi tas lebih dari $10 \%$ dari berat badan anak. 


\section{DAFTAR PUSTAKA}

[1] S. W. Muhammad Syiradjudin, "Pembuatan Prototype Tas Ransel Anak Sekolah dengan Mikrokontroler Arduino Uno," 2016. [Online]. Available: http://repository.narotama.ac.id/119/2/skripsi muhammad syirajudin.pdf.

[2] Legiran, “'Berat Tas Punggung dan Prevalensi Nyeri Punggung Pada Siswa Sekolah Dasar,"” 2017. [Online]. Available:

repository.unsri.ac.id/23484/1/Tas\%2520Sekolah\%2520Artikel\%2520Penelitian\%2520Legiran.p df.

[3] S. V. Dumondor, E. Angliadi, and L. Sengkey, "Hubungan Penggunaan Ransel Dengan Nyeri Punggung Dan Kelainan Bentuk Tulang Belakang Pada Siswa Di Smp Negeri 2 Tombatu," $e$ CliniC, vol. 3, no. 1, pp. 1-5, 2015, doi: 10.35790/ecl.3.1.2015.6824.

[4] K. Walicka-Cuprys̈, R. Skalska-Izdebska, M. Rachwał, and A. Truszczyńska, "Influence of the weight of a school backpack on spinal curvature in the sagittal plane of seven-year-old children," Biomed Res. Int., vol. 2015, 2015, doi: 10.1155/2015/817913.

[5] D. Prihatmoko, "Perancangan Dan Implementasi Pengontrol Suhu Ruangan Berbasis Mikrokontroller Arduino Uno," Simetris J. Tek. Mesin, Elektro dan Ilmu Komput., vol. 7, no. 1, p. 117, 2016, doi: 10.24176/simet.v7i1.495.

[6] I. S. suprapto, sumardi, "Rancang bangun robot mobil pemadam api berbasis mikrokontroler at89s52," pp. 1-9.

[7] K. Pindrayana, R. Indra Borman, B. Prasetyo, and S. Samsugi, "Prototipe Pemandu Parkir Mobil Dengan Output Suara Manusia Mengunakan Mikrokontroler Arduino Uno," CIRCUIT J. Ilm. Pendidik. Tek. Elektro, vol. 2, no. 2, pp. 71-82, 2018, doi: 10.22373/crc.v2i2.3705.

[8] H. Faisal and M. Yusfi, "Rancang Bangun Magnetic Stirrer Berbasis Mikrokontroler At89S52 Dengan Pengaturan Waktu Melalui Keypad," J. Fis. Unand, vol. 2, no. 3, pp. 148-154, 2013, doi: 10.25077/jfu.2.3.

[9] A. Amin, "Monitoring water level control berbasis arduino uno menggunakan lcd $\operatorname{lm} 016 \mathrm{~L}$," $J$. Ilm. Tek. Elektro, vol. 1, no. 2, pp. 41-52, 2018.

[10] S. Utama, A. Mulyanto, M. Arif Fauzi, and N. Utami Putri, "Implementasi Sensor Light Dependent Resistor (LDR) Dan LM35 Pada Prototipe Atap Otomatis Berbasis Arduino," CIRCUIT J. Ilm. Pendidik. Tek. Elektro, vol. 2, no. 2, pp. 83-89, 2018, doi: 10.22373/crc.v2i2.3706. 